\title{
ANALYSIS OF ECONOMIC-FINANCIAL VIABILITY, BY THE MONTE CARLO METHOD, IN SERVICE PROVIDER OF NON- DESTRUCTIBLE TESTS: CASE STUDY
}

\author{
Vanessa Miguel Augusto Souza \\ Universidade Federal Fluminense - UFF, Brazil \\ E-mail:van.hillary@hotmail.com \\ Nilson Brandalise \\ Universidade Federal Fluminense - UFF, Brazil \\ E-mail:nilson_01@yahoo.com.br
}

Submission: 6/22/2019

Revision: 9/18/2019

Accept: 10/9/2019

\section{ABSTRACT}

This work aims to present the economic-financial feasibility, through the application of the Monte Carlo Method, to assist managers in the decision making regarding the investment of a service contract of a company specialized in Non-Destructive Tests, with the tests of Penetrant Liquid and Ultrasound, to which the company that takes the service establishes the requirements previously. The method was apply, in 5000 iterations, from the established parameters, for the initial investment and demand of the test diaries, which provided data regarding the average for the Net Present Value (NPV), Internal Rate of Return (IRR) and Profitability Index (PI), as well as the possible standard deviations, established by the coefficient of variation. Finally, after analyzing the data, it was check that the Method is useful to assist in the making of investment decisions, being feasible the adherence of the contract studied, through the analyzed data and established criteria.

Keywords: Monte Carlo method; viability; non-destructible tests. 
DOI: 10.14807/ijmp.v11i4.1082

\section{INTRODUCTION}

Companies see the need to become competitive, but it is necessary to maintain the Quality Control service, since their products and services must ensure safety in the production process. According to Mendonça and Rangel (2017), "the productive sector of companies in general is composed of production itself, maintenance, planning, quality, purchasing, sales, marketing, human resources, logistics, safety, environment, among others".

The search for Quality Control in the production process makes companies increasingly resort to the Non-Destructive Testing (NDT) services of materials, allowing the analysis of equipment and parts produced, in order to ensure the integrity and safety of them.

The general objective of this work is the analysis of the financial viability for investment, by applying the Monte Carlo Simulation method, in a service provider company, specialized in NDTs, with the Penetrating Liquid and Ultrasound tests. As specific objectives, we highlight the survey of the initial investment and the analysis of the financial return for the same, through contract.

Thus, the problematization is based on the financial analysis of the contracted company, when providing services to the contracting company through the conditions in the contract, because there is a need to analyze the variables that cause impacts on costs and contractual conditions, seeking new strategies to assist managers in decision making, with data that should be considered when preparing the proposal for the company Services Taker. Therefore, this paper seeks to answer the following question: "Is it financially viable for the contracting company to accept the service contract with the available resources?

This article was developed in 7 (seven) chapters, beginning with this introduction that makes a brief contextualization of the theme, presentation of the general and specific objectives, as well as the problematization that originated this work and the reasons that justify it. Chapter 02 brings the literature review, being approached the basic themes of this research, such as: Non-Destructive Tests, Service Provision Contracts, Financial Economic Feasibility Studies and their techniques, the Monte Carlo Method and the Case Study. Chapter 03 sets out the Methodology used. Chapter 04 describes the data collection, followed by their analysis in the following chapter, and the conclusions and recommendations for future works are presented in chapter 06, and finally, in chapter 07, the bibliographic references cited during the course of the work. 
DOI: 10.14807/ijmp.v11i4.1082

\section{LITERATURE REVIEW}

\subsection{Non-Destructible Tests}

The Non-Destructive Tests (NDT) are tests applied on finished or semi-finished parts, necessary to obtain the Quality Control and integrity of parts and equipment. In order not to compromise the operational usefulness of the component to be inspected, it is necessary to inspect it in such a way as not to cause damage to the part or equipment, ensuring that it has its original functionality (FERREIRA, 2008).

Dwivedi, Vishwakarma and Soni (2018), agrees with the definition already presented, emphasizing that "the NDT refers to the process of evaluation or evaluation and inspection of materials or components for characterization or location of defects and failures in comparison with some standards without altering the original attributes or damaging the object being tested". The authors also add that it is possible to test a sample aiming at the economy of the process, or can fully inspect the material to ensure quality control.

Non-destructive testing on structural components may be performed by the following methods according to ABENDI (2019):

- Dimensional: Method used in the various phases of a project, using a wide variety of instruments such as caliper, clinometer, scale, tape measure, micrometer, plumb, levels, squares, in order to determine various measurements.

- Acoustic Emission: Methods applied in metallic equipment, being necessary when a discontinuity is submitted to thermal or mechanical solicitation.

- Radiography: Method used for non-destructive inspection that is based on the differentiated absorption of penetrating radiation by the part being inspected.

- Visual Essay: Method used to identify dimensional changes, pattern of surface finish and in the observation of visual surface discontinuities in materials and products in general, such as cracks, corrosion, deformation, alignment, cavities, porosity, assembly of mechanical systems and many others. It is one of the oldest activities in the industrial sectors, and the first Non-Destructive Testing applied to any type of part or component.

- Penetrating Liquid: Method carried out through the penetration of specific liquids in parts, aiming at the identification of discontinuities in the surface of solid and nonporous materials. 
DOI: 10.14807/ijmp.v11i4.1082

- Magnetic Particles: Method used to detect surface or subsurface damage to magnetic materials.

- Ultrasound: The method is applied to raw materials under inspection during the service maintenance process and is widely used in metallic materials, but can also be applied to plastics, compounds, concrete, wood products and specially related materials.

Faced with the vast options of NDT's, Íñigues, et al. (2010) combined more than one way of performing the test, thus achieving a more reliable result. Therefore, although there is a type of test for a given purpose, the applicability together, combining two or more techniques, will provide a more concrete reliability of the inspected material.

\subsection{Service Contracts}

With the great variety of services present in the market, it is known that often becomes necessary the interaction between organizations, since to provide a quality product or service for stakeholders, companies must be focused on their end activities.

Therefore, there is a relationship of service provision between companies in the market. This relationship modality has greatly contributed to the country's economic development, through the generation of jobs and the important contribution to the national GDP (ROQUE, 2010).

The commercial relationship of service provision should be governed by a written contract, which specifies the details governing the negotiation (DUFFECKER, 2007). Contracts shall be governed clearly and in agreement by all parties involved.

According to Gagliano and Filho (2016), "the service agreement is the legal transaction through which one of the parties, called provider, undertakes to perform an activity for the benefit of another, called borrower, upon remuneration".

\subsection{Economic Feasibility Study - Financial and its techniques}

Organizations should be concerned with analyzing the feasibility of investments before making decisions that involve the expenditure of financial resources or before adhering to funding. In economic-financial feasibility studies, it is necessary to reach a reliable level of estimates of the input and output variables involved (PAZZINI et al., 2015).

In order to perform an efficient analysis of the economic viability, it is necessary to use some techniques capable of identifying the return and costs of the investments made. These techniques are cited as investment criteria in the study conducted by Medrano, Oliveira and 
DOI: 10.14807/ijmp.v11i4.1082

Rodrigues (2009), these authors mention some investment analysis criteria, such as the internal rate of return (IRR), the net present value (NPV), the profitability index (IL) or benefit/cost index (BCI), among others.

NPV is a technique widely used in investment analysis, which consists of assuming a strategy that considers the cost of investments required and the estimate of future cash flows, discounting the interest rate that remunerates the risk assumed by creditors. With this technique, it is recommended to assume the investment if the present value found is greater than zero, that is, if it is positive, otherwise, it is recommended that it be rejected (ALVES; GUIMARÃES; TANNUS, 2012). The formula for calculating NPV is determined in equation 1:

$$
N P V=-I I+\sum_{t}^{n} \frac{F C t}{(1+K)^{t}}
$$

Where:

NPV $=$ Net Present Value

II = Initial investment

FCt $=$ Cash Flow for period $\mathrm{t}$

$\mathrm{k}=$ Minimum required rate of return

In relation to IRR, Pazzini et al. (2015) define it as 'the discount rate that equals the present value of cash inflows with the initial investment associated with a project, making the net present value of an investment equal to zero'. The IRR analysis provides assistance to managers when they are faced with decisions regarding investment opportunities and should reject projects in which the internal rate analyzed is lower than the cost of capital.

According to these authors, the formula for the IRR can be established as follows:

$$
N P V=0=-I I+\sum_{t}^{n} \frac{F C t}{(1+K I R R)^{t}}
$$

Where:

$\mathrm{k}_{\mathrm{IRR}}=\mathrm{IRR}$ rate 
DOI: 10.14807/ijmp.v11i4.1082

Lizote et al. (2014) defines IL as "a variant of the net present value that determines the results found by this method as an index, considering the discounted cash flow". According to the authors, the proposal is economically viable when the IL is greater than or equal to 1 , as this indicates that the monetary return will be equal to or greater than the cash expenditures. Equation 3 is used to find the IL:

$$
I L=\frac{\sum_{t}^{n} \frac{F C t}{(1+\mathrm{k})^{t}}}{I I}
$$

Among the various techniques that allow the analysis of economic and financial viability, Pazzini et al. (2015) suggests the Monte Carlo Method to assist in calculations and analysis through Microsoft Office Excel electronic spreadsheets. According to the authors, the Monte Carlo Method, provides the creation of various scenarios beyond the optimistic, pessimistic and most likely.

\subsection{Monte Carlo Method}

The simulation methods are capable of providing analyses capable of assisting in the decision making process, in order to reduce the probability of uncertainty, Aguiar, Alves and Henning (2010) clarifies that "the simulation should be seen as a tool to support the user in decision making and not as the decision itself". They also add that, in the managerial scope, modeling in mathematical terms is essential to know the variables involved.

Chwif and Medina (2010) differentiate between computational and non-computational simulation, being distinguished by the use of the computer, used as a tool. In practice, usually the simulations are computational, through the construction of a model that can be analyzed, manipulated and controlled so that it becomes close to the understanding of reality (MOREIRA, 2010).

Among the computational simulations, the Monte Carlo method has been applied in different areas of study, such as Finance, Engineering, Statistics, among others. For according to Paula and Dias (2014), Monte Carlo's method can be understood as "a general structure built around the idea of discrete events, developed to help follow a model over time and determine the relevant amounts of interest". Probably due to this definition, Bucchianeri and Coelho (2016) associates the Monte Carlo method with risk management, since it considers it widely used to simulate cost, time and risk variables. 
DOI: 10.14807/ijmp.v11i4.1082

Also according to Bucchianeri and Coelho (2016), Monte Carlo is the "technique used in the Operational Research to simulate possible future scenarios using statistical concepts and random numbers". The authors explain that there is no exact result, since an interval with possible results is presented.

The Monte Carlo formula can be given through the probability density function of the random variable $\mathrm{X}$, according to equation 4 :

$$
F(X)=P(X \in C)=\int_{C}^{x} f(x) d x .
$$

Where:

$\mathrm{F}(\mathrm{x})=$ non-negative function

$\mathrm{C}=$ set of actual numbers

Monte Carlo Simulation has been applied in researches with the objective of assisting managers with investments in projects and economic analysis, and the following studies carried out in recent years are worthy of note:

Arnold and Yildiz (2015) used Monte Carlo Simulation to analyze transaction costs and financial risks involved in renewable energy technology investment projects;

Melek (2016) also uses the Monte Carlo Method to evaluate the revenue flow in function of the marginal operating cost, aiming at verifying the possibility of increasing the revenue of two small hydroelectric plants located in Santa Catarina;

Lammoglia and Brandalise (2019) used the Monte Carlo Simulation to verify the financial viability of a photovoltaic matrix in the distributed microgeneration model from the perspective of the residential consumer, thus developing a tool that proved to be reliable to support decision making.

\subsection{Case Study}

The case study investigates a fact that occurs in reality, which does not have its limits clearly established and limited in order to analyze it, through the creation of hypotheses that can identify the variables involved (YIN, 2010). Thus, the Case Study has been constantly applied, as an investigative means, in order to achieve detailed knowledge of a given object, which can be used in exploratory research, acting in order to crush real situations, descriptive 
DOI: 10.14807/ijmp.v11i4.1082

researches when discussing a given context, or explanatory researches when clarifying the variables that cause impacts in complex cases (GIL, 2008).

Yazan's research (2016) proposed to the researcher to "become familiar with different approaches to case studies... They can choose to use the tools offered by any of the Methodologists or to compose an amalgam of tools from two or three of them". The author presents the approach of the three fundamental authors in the methodological area: Stake (1995) writes for the researchers who intend to use his writings as methodology, while Merriam (1998) intends to focus on the general principles of the case study, emphasizing its use in qualitative research, and Yin (2002) aims to fill the gap of previous authors, contributing beyond theoretical research, but also offering guidance and how to go through a case study.

Gil (2010) also adds that "in most case studies it is possible to distinguish four phases: a) delimitation of the case-unit; b) data collection; c) analysis and interpretation of data; d) writing the report".

Regarding the researcher, Andrade et al. (2017) emphasizes that "the case study as a research method requires the researcher to take care of the protocol design, explaining the formal procedures and recognizing the strengths and limitations of the study".

\section{METHODOLOGY}

This research is established through surveys of initial investment data of the company providing services of NDTs, in order to identify the investment for the fulfillment of the contract signed with the contracting company. Thus, this study can be classified as descriptive, which according to Gil (2010, p. 42) seeks to determine the nature of the relationship between the association of identified variables. Still, according to the author, some descriptive researches are approximate to exploratory ones when their result provides a new view of the initial problem.

In parallel with the surveys of quantitative data of the investment of adhesion of the service contract in NDT, qualitative data were also collected through techniques of bibliographic research and documentary research, since this study seeks to identify the conditions established in the service contract prepared in commercial negotiation between the two companies involved, in order to identify data that refer to the validity, values and payment term.

And the work is still a case study, since it aims to explore real situations that do not have clearly defined limits, in order to describe the situation in which the investigation is being 
DOI: 10.14807/ijmp.v11i4.1082

done, seeking to explain the variables that cause a certain phenomenon in complex situations (GIL, 2008).

After identifying the contractual data and the costs involved in the initial investment for each type of inspection, parameters were projected for the annual costs and expenses, as well as for the quantity demanded by the contracting company. From the parameterization the data were launched in the Microsoft Excel spreadsheet, through the formula "= Random ( )" in order to ensure the randomness and independence of the simulation of data, facilitating the analysis of data and results.

In the initial investment, the triangular function was used, where a more likely value was established, and $20 \%$ was deducted to calculate the minimum value and $20 \%$ added to calculate the maximum value. This percentage was used due to the analysis of historical data, where there are variations of $20 \%$ in investment costs related to working capital, in the analyzed period, which may be justified by the variation in prices of inputs used and by the Variable Labor, which in turn are proportional to the demand for the performance of LP activities.

As for the amount of demanded per diems, the minimum amount of 0 was considered, considering that there is no request from the contracting company in the period of 1 year, the assumption that all inspectors perform activities every day in the modalities for which they were hired was considered as the maximum value, and the most likely value is that it has only $50 \%$ of the labor resource being used for most of the year.

The values of NPV, IRR and IL were identified through 5,000 interactions in probabilistic simulations, being performed the analysis through statistical summary, histogram and graph of the mean and standard deviation, in order to assist managers in making decisions regarding adherence to the contract.

\section{DATA COLLECTION}

When analyzing the contract concluded between the parties, it was found that it has a duration of three years. Among the duties of the contractor is the supply of skilled labor, as well as all inputs and equipment necessary for the implementation of NDTs requested by the contracting company. Among the various specifications of the existing tests, the contract refers to the execution of Penetrating Liquid and Ultrasound.

The contract is contemplated by the maximum amount of 2,228 days of Penetrating Liquid and 1,682 days of Ultrasound, because each inspector represents one day, but the 
DOI: 10.14807/ijmp.v11i4.1082

contracting party does not guarantee the demand of activity for every day, being possible days in which the inspectors are idle.

The initial investment was estimated at $\mathrm{R} \$ 100,000.00$, distributed in $\mathrm{R} \$ 2,300.00$ of furniture for assembling the office structure, $\mathrm{R} \$ 3,000.00$ for computers, printers and cameras, $\mathrm{R}$ \$ 6,500.00 for gas detectors, in addition to investments in uniforms, occupational exams, personal protection equipment, work safety documentation and the qualification of employees, which total $\mathrm{R} \$ 9,400.00$ and which are required annual disbursements. In addition, an estimated investment of $\mathrm{R} \$ 57,200.00$ in ultrasound equipment and $\mathrm{R} \$ 600.00$ in sprayers is required to carry out the activity in Penetrating Liquid.

The amount of $R \$ 21,000.00$ is also included in the initial investment, referring to the working capital necessary to cover the expenses with office supplies, cleaning material, rent and fuel for the vehicle, which occurred in the first year.

In order to calculate the costs and indirect expenses present in the initial investment, it is necessary to apportion them, and to do so, the amount of contracted per diems for each inspection category is used as the basis for apportionment, as calculated in table 1 .

Table 1: Calculation of Apportionment of Per Diems

\begin{tabular}{lcr}
\hline \multicolumn{3}{c}{ Apportionment } \\
\hline \multicolumn{1}{c}{ Type of NDT } & Daily Contracts & Percentage \\
\hline Penetrating Liquid & 2,228 & $56.98 \%$ \\
Ultrasound & 1,682 & $43.02 \%$ \\
\hline Total: & $\mathbf{3 , 9 1 0}$ & $\mathbf{1 0 0 . 0 0 \%}$ \\
\hline \multicolumn{3}{c}{ Source: Prepared by the authors (2019) }
\end{tabular}

In possession of the percentage to be applied for investment sharing, Table 2 presents the initial investment that are of each modality, and adds the investment of equipment and tools that are particular to each test.

Table 2: Initial Investment

\begin{tabular}{lrrr}
\hline \multicolumn{1}{c}{ Specification } & Investimento & & \\
\hline \multicolumn{1}{c}{ Value } & LP & US \\
\hline Office furniture & $\mathrm{R} \$ 2,300.00$ & $\mathrm{R} \$ 1,310.59$ & $\mathrm{R} \$ 989.41$ \\
Computers, Printers and Cameras & $\mathrm{R} \$ 3,000.00$ & $\mathrm{R} \$ 1,709.46$ & $\mathrm{R} \$ 1,290.54$ \\
Gas Detectors & $\mathrm{R} \$ 6,500.00$ & $\mathrm{R} \$ 3,703.84$ & $\mathrm{R} \$ 2,796.16$ \\
Uniforms & $\mathrm{R} \$ 700.00$ & $\mathrm{R} \$ 398.86$ & $\mathrm{R} \$ 301.14$ \\
Occupational Exams & $\mathrm{R} \$ 700.00$ & $\mathrm{R} \$ 398.86$ & $\mathrm{R} \$ 301.14$ \\
Safety Equipment & $\mathrm{R} \$ 2,000.00$ & $\mathrm{R} \$ 1,139.60$ & $\mathrm{R} \$ 860.40$ \\
Occupational Safety Documentation & $\mathrm{R} \$ 2,000.00$ & $\mathrm{R} \$ 1,139.60$ & $\mathrm{R} \$ 860.40$ \\
Employee Qualification & $\mathrm{R} \$ 4,000.00$ & $\mathrm{R} \$ 2,279.20$ & $\mathrm{R} \$ 1,720.80$
\end{tabular}


INDEPENDENT JOURNAL OF MANAGEMENT \& PRODUCTION (IJM\&P)

http://www.ijmp.jor.br

v. 11, n. 4, July - August 2020

ISSN: 2236-269X

DOI: 10.14807/ijmp.v11i4.1082

\begin{tabular}{lrrr} 
Working Capital & $\mathrm{R} \$ 21,000.00$ & $\mathrm{R} \$ 11,965.80$ & $\mathrm{R} \$$ 9,034.20 \\
Ultrasound Equipament & $\mathrm{R} \$ 57,200.00$ & ---- & $\mathrm{R} \$ 57,200.00$ \\
Sprayers for Penetrating Liquid & $\mathrm{R} \$ 600.00$ & $\mathrm{R} \$ 600.00$ & $--\cdot-$ \\
\hline TOTAL: & $\mathbf{R} \mathbf{1 0 0 . 0 0 0 , 0 0}$ & $\mathbf{R} \$ \mathbf{2 4 . 6 4 5 , 8 1}$ & $\mathbf{R} \mathbf{7 5 . 3 5 4 , 1 9}$ \\
\hline
\end{tabular}

For the investment values and quantity of demanded daily rates, parameters were presented, according to table 3 , and the values that present the quantities of daily rates were estimated for the annual period.

Table 3: Established Parameters

\begin{tabular}{lrrr}
\hline \multicolumn{1}{c}{ Specification } & Minimum & \multicolumn{1}{c}{ Maximum } & \multicolumn{1}{c}{ Most Likely } \\
\hline LP units & 0 & 960 & 480 \\
Initial Investiment LP & $\mathrm{R} \$ 19,000.00$ & $\mathrm{R} \$ 28,750.00$ & $\mathrm{R} \$ 24,000.00$ \\
US units & 0 & 480 & 240 \\
Initial Investiment US & $\mathrm{R} \$ 60,000.00$ & $\mathrm{R} \$ 90,000.00$ & $\mathrm{R} \$ 75,000.00$ \\
\hline \multicolumn{4}{l}{}
\end{tabular}

Also in view of the contractual conditions, the management of the Service Provider company opted to hire a total of 4 inspectors to meet the contract, two being inspectors exclusively to meet the demand for Penetrating Liquid and two other inspectors who are qualified to meet the demand for Penetrating Liquid and Ultrasound, simultaneously.

It is known that the manner in which inspectors are hired is consistent with the base salary in the tax calculation portfolio, but the actual salary is variable, being proportional to $45.16 \%$ of the value of the daily rates executed in the contract, in addition to the fixed payroll charges of R \$507.00 per Penetrating Liquid Inspector, and R \$543.17 per Ultrasound Inspector.

As variable costs, in addition to labor involving charges, we highlight the cost of inputs used to perform the Penetrating Liquid activity, estimated at $\mathrm{R} \$ 51.74$ on average per day, and also the incidence of charges of $16.25 \%$ on the Invoice of sales.

The service provider company is taxed on the assumed profit, therefore the taxes levied on the invoice are in relation to 5\% Service Tax (ISS), $0.65 \%$ of the Social Interaction Program (PIS), 3\% of Social Security Financing Contribution (COFINS), 4.8\% of Corporate Income Tax (IRPJ) and $2.8 \%$ of Social Contribution on Net Profit (CSLL), which total $16.25 \%$ of charges on the service rendering invoice.

To analyze the economic viability of the contract in question, the rate required to calculate the cash flow in present value for the three-year term of the contract was $6.5 \%$ per year (a.a.), which represents the Selic rate for the current year, as informed by the Central Bank of Brazil (2019). 
DOI: 10.14807/ijmp.v11i4.1082

\section{DATA ANALYSES}

In possession of the data collected, the values already established for the price of the LP and US daily rates, the Selic rate required for the analysis of the project, the current term of the contract, and the tax rate on the invoicing of the services rendered, in addition to the data on initial investment and quantity demand that were previously parameterized.

After performing the simulation it was possible to obtain the data regarding the minimum, mean and maximum values of the project, as well as the median, standard deviation and coefficient of variation, as shown in table 4.

Table 4: NPV, IRR and IL statistics

\begin{tabular}{|c|c|c|c|}
\hline & & \multicolumn{2}{|c|}{ Statistical measures } \\
\hline & NPV & IRR & IL \\
\hline Minimum & $-\mathrm{R} \$ 129,877.00$ & $-34.56 \%$ & -0.68 \\
\hline Maximum & $\mathrm{R} \$ 890,269.00$ & $363.78 \%$ & 10.49 \\
\hline Expected value & $\mathrm{R} \$ 412,671.00$ & $171.54 \%$ & 5.13 \\
\hline Median & $\mathrm{R} \$ 421,919.00$ & $173.60 \%$ & 5.18 \\
\hline Standard deviation & $\mathrm{R} \$ 163,923.00$ & $60.58 \%$ & 1.66 \\
\hline Coefficient of variation & 0.40 & 0.35 & 0.32 \\
\hline
\end{tabular}

Table 5 shows the probability of achieving positive NPV, IRR $>6.5 \%$ and IL $>1$ :

Table 5: Measures of probability calculation

\begin{tabular}{llllll}
\hline \multicolumn{1}{c}{$\boldsymbol{N P V}$} & \multicolumn{2}{c}{ IRR } & IL \\
\hline$N P V>$ & $\mathrm{R} \$ 0.00$ & $\mathrm{IRR}<$ & $6.5 \%$ & $\mathrm{IL}>$ & 1.0 \\
$p(\mathrm{NPV}>)$ & $99.41 \%$ & $\mathrm{p}(\mathrm{IRR}<)$ & $0.32 \%$ & $\mathrm{p}(\mathrm{IL}>)$ & $99.36 \%$ \\
\hline \multicolumn{5}{c}{ Source: Prepared by the authors (2019) }
\end{tabular}

In observance of table 4, it is concluded that through the simulation, the average NPV obtained is $\mathrm{R} \$ 412,671.00$, with a standard deviation of $\mathrm{R} \$ 163,923.00$, that is, a coefficient of variation of $40 \%$. Through the simulations performed, the NPV obtained the minimum value of negative $\mathrm{R} \$ 129,877.00$, representing the situation in which the project should be rejected, however, according to table 5, the probability of obtaining positive NPV is $99.41 \%$.

The IRR will have a negative percentage in situations in which the NPV is also negative, being able to find a minimum value of $-34.56 \%$ for this rate, and a maximum value of $363.78 \%$, however, on average, the IRR achieved is $171.54 \%$, with a coefficient of variation of $32 \%$, as shown in table 4 . An analysis of table 5 shows that the probability of obtaining the IRR lower than $6.5 \%$ is only $0.32 \%$, so we have the probability of $99.68 \%$ of acceptance of the project when analyzing this rate.

Regarding the IL, the minimum value found was -0.68 , but with minimal possibility of occurrence, the maximum value found is 10.49 , but the expected value through the simulation 
DOI: 10.14807/ijmp.v11i4.1082

of 5,000 interactions is 5.13, which justifies the acceptance of the project, which is recommended when this index exceeds 1 . It is also worth mentioning that when considering the standard deviation found, the project still remains advantageous, because by deducting the value of 1.66 from the standard deviation, it continues to obtain the IL greater than 1, and according to table 5, there is a probability of $99.36 \%$ of the occurrence of this fact.

During the execution of the simulation with 5,000 interactions, the figure 1 was constructed, consisting of a histogram graph representing the frequency with which each set of classes of NPV occurs.

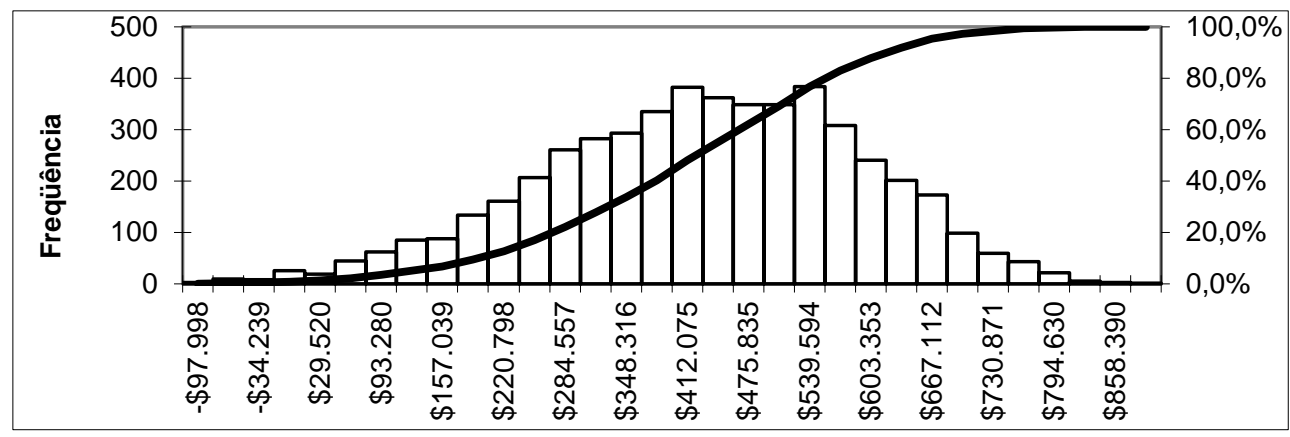

Figure 1: NPV frequency

Source: Prepared by the authors (2019)

When analyzing table 4, it is observed that the maximum value found was $\mathrm{R} \$ 890,269$, which according to figure 1 , has minimal possibilities of occurring, with a possibility close to 0 . The median found was $\mathrm{R} \$ 421,919.00$, but this value occurs in the same frequency class as the mean, as can be seen in figure 1, which leads to the conclusion that the values do not present high discrepancies between the mean and the central value.

The NPV coefficient of variation is shown graphically in figure 2, where it shows the sequence of the mean and standard deviation of the NPV's. Small oscillations can be observed as the volume of simulations increases.

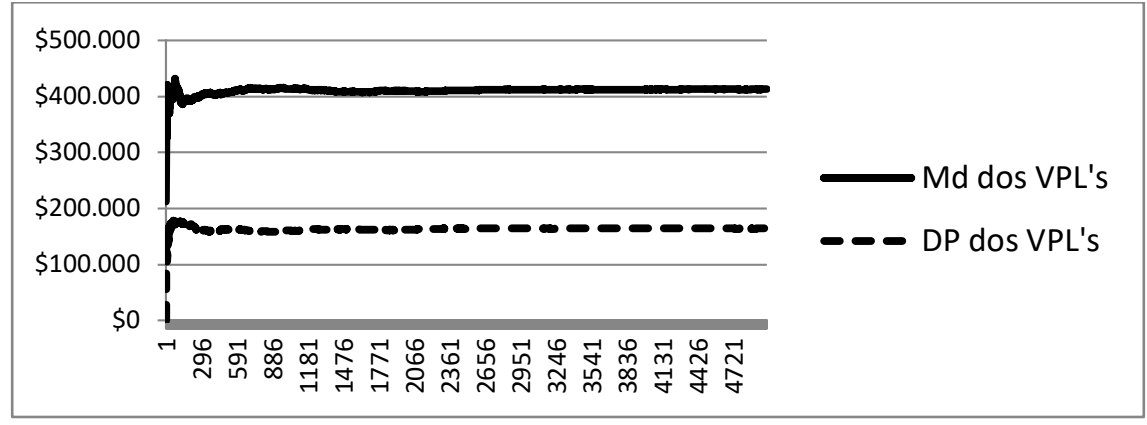

Figure 2: Mean and Standard Deviation of NPV

Source: Prepared by the authors (2019) 
DOI: 10.14807/ijmp.v11i4.1082

Note that the distance between the mean and the standard deviation is approximately $40 \%$, from a certain number of simulations, confirming the value of the coefficient of variation found in table 4. It is also observed that the greater the number of interactions, the greater the probability of finding the most accurate standard deviation.

\section{CONCLUSION}

In view of the analysis of the simulation performed, it is recommended to invest in the project studied, since it has a probability of $99.41 \%$ of obtaining positive NPV, a probability of $68 \%$ of IRR being higher than the minimum rate of attractiveness and $99.36 \%$ of the probability of IL being higher than 1 .

Another considerable factor that contributes to the investment decision in the contract is the fact that the standard deviation found in the statistical measures of NPV, IRR and IL does not have sufficient value to leave the project unfeasible in view of the established parameters.

It is recommended to carry out other studies through this theme, mainly through the application of other indicators that enable the analysis of economic feasibility, as well as the application of other methods, and in the future can be performed the analysis from historical data of cash flows.

\section{REFERENCES}

ABENDI - Associação Brasileira de Ensaios Não Destrutivos e Inspeção (2019) Ensaios não destrutivos. Available in: http://www.abendi.org.br/abendi/default.aspx?s=19. Access in: $13 / 04 / 2019$

AGUIAR, G.; ALVES, C. C.; HENNING, E. (2010) Gerenciamento de Projetos: Simulação de Monte Carlo via a Ferramenta SimulAr. São Carlos, SP. XXX ENEGEP.

ALVES, E. M.; GUIMARÃES, M. P.; TANNUS, S. P. (2012) Análise de viabilidade de projeto para implantação de uma academia esportiva baseada no conjunto de conhecimentos em gerenciamento de projetos (guia pmbok®).Bento Gonçalves, RS. XXXII ENEGEP.

ANDRADE, S. R.; et al. (2017) O Estudo De Caso Como Método De Pesquisa Em Enfermagem: Uma Revisão Integrativa. Texto \& Contexto - Enfermagem, Florianópolis, v. 26, n. 4, p. 1- 12, 2017. ISBN: 1700536001. ISSN: 1980-265X, DOI: 10.1590/010407072017005360016.

ARNOLD, O.; YILDIZ, O. (2015) Economic Risk Analysis of Decentralized Renewable Energy Infrastructures - A Monte Carlo Simulation Approach. Renewable Energy, v. 77, p. 227-239.

BCB - Banco Central Do Brasil (2019) Taxa Selic. Available in: http://www.bcb.gov.br/controleinflacao/taxaselic/. Access in: 06/06/2019 
BUCCHIANERI, J. R.; COELHO, C. J. (2016) Previsão de demanda por simulação de Monte Carlo em uma franquia especializada em produtos de beleza. Anais do XLVIII SBPO Simpósio Brasileiro de Pesquisa Operacional.

CHWIF, L.; MEDINA, A. C. (2010) Modelagem e Simulação de Eventos Discretos, Teoria \& Aplicações, 3. ed. São Paulo: Ed do autor.

DWIVEDI, S. K.; VISHWAKARMA, M.; SONI, A. (2018) Advances and Researches on Non Destructive Testing: A Review. Materials Today: Proceedings, n. 5/2, p. 3690-3698.

DUFFECKE, R. (2007) A importância do contrato de prestações de serviços contábeis. Revista Intersaberes, y. 2 n. 4, p. 241 - 247. ISSN: 1809-7286

FERREIRA, R. C. R. (2008) Influência do fator humano em ensaios não destrutivos por correntes parasitas na manutenção de estruturas aeronáuticas. 85 f. Dissertação (Mestrado em Engenharia de Produção) - Universidade Federal de Itajubá, Itajubá.

GAGLiAnO, P. A.; FILHO, R. P. (2016) Novo curso de Direito Civil - Contratos em Espécie, 9. Ed., v. 4, fl. 275. São Paulo.

GIL, A. C. (2008) Métodos e Técnicas de Pesquisa Social. 6 ed. São Paulo: Atlas.

GIL, A. C. (2010) Como Elaborar Projetos de Pesquisa. 5 ed. São Paulo: Atlas.

ÍÑIGUES, G.; ARRIAGA, F.; ESTEBAN, M. (2010) In situ non-destructive density estimation for the assessment of existing timber structures. Proc. 10th World Conf. Timber Eng., Riva di Garda, Italy, p. 1124-1149

LAMMAOGLIA, J. A. M.; BRANDALISE, N. (2019) Analysis of economic viability with the use of monte carlo simulation for microgeneration of photovoltaic energy. Independent Journal of Management \& Production, v. 10, n. 3, p. 1000-1014. DOI: 10.14807/ijmp.v10i3.876

LIZOTE, S. A.; ANDRADE, D. A.; SILVA, F.; PEREIRA, R. S.; PEREIRA, W. S. (2014) Análise de Investimentos: um Estudo Aplicado em uma Empresa do Ramo Alimentício. Artigo Científico, XI Simpósio de Excelência em Gestão e Tecnologia. Rio de Janeiro.

MEDRANO, J. H. P.; OLIVEIRA, J. V.; RODRIGUES, L. C. (2009) Critérios de Investimentos em Projetos, uma Visão com Base no Planejamento Estratégico. VII Simpósio de Excelência em Gestão e Tecnologia. Rio de Janeiro.

MELEK, V.C. (2016) Operação de PCH’s com ênfase no aspecto negocial. 11 fl., Dissertação (Pós Graduação em Engenharia de Recursos Hídricos e Ambiental) Universidade Federal do Paraná, Curitiba, Paraná.

MENDONCA, T. C.; RANGEL, L. A. D. (2017)Priorização de Equipamentos em Manutenção Empregando o Apoio Multicritério à Decisão. Blumenau, SC. Anais do XLIX Simpósio Brasileiro de Pesquisa Operacional.

MERRIAM, S. B. (1998) Qualitative research and case study applications in education. San Francisco: Jossey-Bass.

MOREIRA, D. A. (2010) Pesquisa Operacional: Curso Introdutório.2.ed. São Paulo: Cengage Learning.

PAULA, R. R.; DIAS, M. S. (2014) Método de Monte Carlo e Aplicações. 11 fl. Trabalho de Conclusão de Curso - (Matemática) - Universidade Federal Fluminense (UFF), Volta Redonda, RJ. 
PAZZINI, H. S.; MURTA, A. L. S.; MOTTA, C. K.; STRINGARI, D. (2015) Viabilidade econômica e simulação de monte carlo da produção de biodiesel de resíduos de soja. Revista Brasileira de Administração Científica, Aquidabã, v. 6, n. 1, p.76-91. DOI: http://dx.doi.org/10.6008/SPC2179684X.2015.001.0005

ROQUE, N. C. (2010) A prestação de serviços e o Código de Defesa do Consumidor: Os cuidados que devem ser tomados pelo fornecedor. Olimpia. Scientia FAER, Olímpia - SP, y. 2, v. 2.

STAKE, R. E. (1995) The art of case study research. Thousand Oaks: SAGE Publications.

YAZAN, B. (2016) Traducao de Ivar Cesar Oliveira. Tres abordagens do método de estudo de caso em educação: Yin, Merriam e Stake. Revista Meta: Avaliação, [S.l.], v. 8, n. 22, p. 149-182, may 2016. ISSN 2175-2753. Available in:

http://revistas.cesgranrio.org.br/index.php/metaavaliacao/article/view/1038. Access in: 03 may 2019. DOI: http://dx.doi.org/10.22347/2175-2753v8i22.1038.

WARREN, C. S.; REEVE, J. M.; FESS, P. E. (2001) Contabilidade Gerencial. São Paulo: Pioneira Thomsom Learning.

YIN, R. K. (2002) Case study research: design and methods. Thousand Oaks: SAGE Publications.

YIN, R. K. (2010) Estudo de caso: planejamento e métodos. Tradução Ana Thorell; revisão Técnica Cláudio Damacena. - 4. ed.- Porto Alegre: Bookman. 